University of Nebraska - Lincoln

DigitalCommons@University of Nebraska - Lincoln

Publications, Agencies and Staff of the U.S.

Department of Commerce

U.S. Department of Commerce

2011

Migration and behavior of juvenile North Pacific albacore

(Thunnus alalunga)

John Childers

NOAA Fisheries, John.Childers@noaa.gov

Stephanie Snyder

NOAA Fisheries

Suzanne Kohin

NOAA Fisheries

Follow this and additional works at: https://digitalcommons.unl.edu/usdeptcommercepub

Part of the Environmental Sciences Commons

Childers, John; Snyder, Stephanie; and Kohin, Suzanne, "Migration and behavior of juvenile North Pacific albacore (Thunnus alalunga)" (2011). Publications, Agencies and Staff of the U.S. Department of Commerce. 252.

https://digitalcommons.unl.edu/usdeptcommercepub/252

This Article is brought to you for free and open access by the U.S. Department of Commerce at DigitalCommons@University of Nebraska - Lincoln. It has been accepted for inclusion in Publications, Agencies and Staff of the U.S. Department of Commerce by an authorized administrator of DigitalCommons@University of Nebraska - Lincoln. 


\section{Migration and behavior of juvenile North Pacific albacore (Thunnus alalunga)}

\section{JOHN CHILDERS,* STEPHANIE SNYDER AND SUZANNE KOHIN}

NOAA Fisheries, Southwest Fisheries Science Center, 8604 La Jolla Shores Dr., La Jolla, CA 92037-1508, USA

\begin{abstract}
Archival tags were used to study the seasonal movements, migration patterns and vertical distribution of juvenile North Pacific albacore (Thunnus alalunga). Between 2001 and 2006, archival tags were deployed in North Pacific albacore in two regions of the Northeast Pacific: (i) off Northern Baja California, Mexico and Southern California, and (ii) off Washington and Oregon. Twenty archival tagged fish were recovered with times at liberty ranging from 63 to 697 days. Tagged albacore exhibited five distinct, seasonal migratory patterns. Depth and temperature data also showed a broad range of vertical behaviors. In certain regions such as off Baja California, Mexico, juvenile albacore make frequent dives to depths exceeding $200 \mathrm{~m}$ during the day and remain in the surface mixed layer at night, whereas off Oregon and Washington they remain near the surface both day and night. Water temperatures encountered ranged from 3.3 to $22.7^{\circ} \mathrm{C}$. Peritoneal temperatures were significantly higher by an average of approximately $4^{\circ} \mathrm{C}$, as expected in these warm-bodied fish. This study provides a comprehensive examination of horizontal and vertical movements of juvenile albacore in the Northeast Pacific. The results reveal diverse behavior that varies regionally and seasonally as albacore move among different habitats throughout the entire North Pacific.
\end{abstract}

Key words: archival tags, geolocation, habitat preferences, North Pacific albacore, seasonal migration, Thunnus alalunga, vertical behavior

*Correspondence. e-mail: John.Childers@noaa.gov

Received 17 March 2010

Revised version accepted 26 December 2010

Published 2011. This article is a US Government work and is in the public domain in the USA.

\section{INTRODUCTION}

Albacore (Thunnus alalunga, Bonnaterre, 1788) are globally distributed in temperate and tropical waters (Collette and Nauen, 1983). In the Pacific they are believed to be separated into North and South Pacific stocks at the equator, with separate spawning grounds evident for the two stocks (Nakamura, 1969; Ueyanagi, 1969; Sund et al., 1981). Throughout the North Pacific, albacore are harvested by commercial fisheries from several countries, including Japan, Taiwan, Korea, Mexico, Canada and the U.S.A. The U.S. troll and pole-and-line commercial fisheries operate along the U.S. West Coast and offshore into the North Pacific Transition Zone (NPTZ) and catch predominantly juvenile albacore, aged 2-5 years. Between 2000 and 2008, these U.S. commercial surface fisheries accounted for an average of approximately $14 \%$ of the total annual catch of albacore in the North Pacific (Childers and Betcher, 2010). U.S. recreational fisheries accounted for an additional $1-2 \%$ of the total annual catch (Childers and Betcher, 2010). Periodic north-south distributional shifts occur in the U.S. commercial surface albacore fishery. Historically, there have been periods of up to 25-30 years when the fishery was confined mostly to California waters, followed by periods of 15-20 years when the fishery shifted to waters principally centered off Oregon, Washington and British Columbia, Canada (Brock, 1943; Clemens and Craig, 1965; Clark et al., 1975).

The influences of climatic shifts and oceanographic conditions have been studied previously, but the availability of new technologies with increased resolution of oceanographic measurements grants the ability to expand the knowledge of the movement and distribution of North Pacific albacore. The important economic value of albacore to commercial fisheries throughout the North Pacific has led to considerable research effort using methods such as conventional tags and catch data analysis (Clemens, 1961; Clemens and Craig, 1965; Laurs and Lynn, 1977). Studies using conventional tags have shown that North Pacific albacore make extensive, seasonal migrations throughout their lives (Otsu, 1960; Clemens, 1961; Otsu and Uchida, 1963; Rothschild and Yong, 1970;

doi:10.1111/j.1365-2419.2011.00575.x 157 
Laurs and Lynn, 1977; Ichinokawa et al., 2008). Based on tag returns between 1952 and 1958, Otsu and Uchida (1963) developed a model of North Pacific albacore migration throughout their life cycle. Their model hypothesized that albacore from ages 2 to 5 migrate from the coast of Oregon (in October) and from the coast of Japan (in June) to an area centered at $40^{\circ} \mathrm{N}, 180^{\circ}$. According to their model, upon which they conclude that North Pacific albacore constitute a single stock, the fish stay in that offshore area until February or March and then migrate either to the coast of southern California or Baja California, Mexico (arriving in August), or to Japan (arriving in May). While their model has been widely accepted and has served as the basis for other related studies (e.g., Ichinokawa et al., 2008), some uncertainty remains about the migratory patterns and population structure of North Pacific albacore. Tagging studies conducted by the U.S. commercial surface fleets between 1971 and 1978 indicated that two sub-stocks may exist along the west coast of North America based on limited mixing and different growth rates between albacore caught either north or south of $40^{\circ} \mathrm{N}$ (Laurs and Lynn, 1977; Laurs and Wetherall, 1981).

Several previous studies have linked the horizontal movements of albacore to oceanographic conditions. By combining in situ oceanographic data with conventional tag data and catch data, it has been shown that young albacore have a preference for sea surface temperatures (SSTs) between 15 and $18^{\circ} \mathrm{C}$ (Clemens, 1961; Laurs et al., 1977). Using more advanced remote sensing capabilities to link SST and ocean color data to concurrent albacore commercial fishery catch data, the areas with highest albacore catch off Central and Northern California were found to be related to coastal upwelling boundaries; high concentrations of albacore were found on the oceanic side of the upwelling boundaries in the warmer $\left(>16^{\circ} \mathrm{C}\right)$, blue (<0.3 $\mathrm{mg} \mathrm{m}^{-3}$ chlorophyll) water (Laurs et al., 1984). In addition, the distribution of albacore in the North Pacific was found to be concentrated around the transition-zone chlorophyll front (Polovina et al., 2001); albacore catch was greatest where chlorophyll levels were approximately $0.2 \mathrm{mg} \mathrm{m}^{-3}$. Higher catch rates have also been linked to areas of high eddy kinetic energy in the Central and Western North Pacific (Zainuddin et al., 2006).

Advances in electronic tagging technologies have enabled more detailed investigations into juvenile albacore behavior and their habitat use. The ability to track individual fish, both vertically and horizontally, over a broad range of oceanographic conditions provides greater insights into the relationship between the environment and their behaviors. Historically, the thermocline was thought to act as a barrier to the vertical distribution of juvenile albacore, thus confining their movements to the upper mixed layer (Clemens, 1961); however, acoustic tracking studies overturned this hypothesis. Observations of juvenile albacore diving behavior were combined with concurrent in situ environmental measurements in the vicinity of tracked animals to demonstrate that juvenile albacore spend substantial time below the thermocline, particularly during the day (Laurs, 1983). While acoustic tracking methods provide highly detailed information, the duration of tracks tends to be short and sample sizes are often too limited to make inferences about large-scale movement and habitat use (Arnold and Dewar, 2001).

The Southwest Fisheries Science Center of the National Marine Fisheries Service in collaboration with the American Fishermen's Research Foundation began using archival tags in 2001 to study the movements and environmental preferences of albacore in the Northeast Pacific. Archival tags that collect depth, temperature and light-level information have been used successfully since the mid-1990s on a number of other tunas to study their movements and habitat preferences (e.g., Gunn et al., 1994; Arnold and Dewar, 2001; Block et al., 2001; Schaefer and Fuller, 2002; Kitagawa et al., 2007; Teo et al., 2007). A previous study using archival tags in North Pacific albacore reported only a single return and thus limited information (Uosaki, 2006), and the use of pop-off archival tags on South Pacific albacore has not provided long time series (Domokos et al., 2007).

The primary objectives of the study were to obtain details on the seasonal migratory movements of juvenile albacore into and out of the U.S. commercial and recreational fisheries along the west coast of North America and to examine their horizontal and vertical habitat utilization. The value of these commercial and recreational fisheries to local economies, and the continuing uncertainty about stock structure of albacore in the North Pacific, makes it crucial to understand albacore migratory behavior and oceanographic influences on their distribution. This is the first comprehensive report on the use of implanted archival tags in albacore.

\section{MATERIALS AND METHODS}

\section{Electronic tags}

The tags used in this study were Wildlife Computers (Redmond, WA) model MK9 ( $N=208)$, Lotek Wireless (Ontario, Canada) model LTD2310 ( $N=281)$, and

Published 2011. This article is a US Government work and is in the public domain in the USA., Fish. Oceanogr., 20:3, 157-173. 
Northwest Marine Technology (now Lotek Wireless; $N=15$ ) geolocating archival tags. Each tag consists of a small cylindrical body approximately $7 \mathrm{~cm}$ long with a stalk approximately $20 \mathrm{~cm}$ long and is capable of recording pressure, light, and peritoneal and ambient water temperatures. The tags were programmed to record sensor readings every minute.

Each tag was tested prior to deployment. When received from the manufacturer, the tags were programmed, activated, and left for 1-3 months in a saltwater bath. The recordings from the testing period were examined for evidence of any sensor malfunction, and tags showing questionable performance were sent back to the manufacturers for repair or replacement.

\section{Deployments}

There are generally two oceanographic areas with high albacore abundance during the summer and fall months in the eastern North Pacific: (i) off Northern California, Oregon and Washington, where the U.S. commercial troll and pole-and-line fleets have concentrated their fishing effort in recent years, and (ii) off northern Baja California, Mexico, and Southern California, where albacore are predominantly targeted by sport fishers. Within this paper, these areas will be referred to as the 'northern fishery area' and 'southern fishery area', respectively.

It was initially unknown whether albacore would survive the catch, surgery and release, and carry these tags in their abdomen without ill effects (due to their small size relative to other fish implanted with these types of tags). Therefore, in the early stages of the project, dummy tags of the same external design as the Wildlife Computers MK9 tag but lacking electronic components were deployed; however, once expertise was developed with the catch, surgery and release procedures, and because expected return rates based on conventional tag returns were estimated to be only $5 \%$, electronic tag deployments were begun without waiting for dummy tag returns. Deployment and recovery information from dummy tag recaptures were not used in the horizontal habitat-use analyses described in this paper.

Tags were deployed in both the northern and southern fishery areas in the summer and fall aboard chartered commercial and sport fishing vessels. Albacore were caught using rod and reel, handline, troll, and pole-and-line gears. Only fish that were greater than $55 \mathrm{~cm}$ straight fork length (FL) and deemed to have minimal or no injury were selected for tagging. Once a suitable fish was captured, it was gently placed on its back in a canvas tagging cradle. The head and eyes were covered with a wet chamois cloth, the hook removed, and the gills irrigated with seawater. A small incision was made in the posterior section of the abdomen, off the centerline, and a blunt trocar was used to penetrate the peritoneum. Tags were implanted in the peritoneal cavity with the sensor stalk projecting out toward the tail of the fish. The incision was closed using two dissolvable sutures positioned around the exiting stalk. Data collected at the time of tagging included latitude, longitude, date, time, FL and SST. Each tagging operation generally took $5 \mathrm{~min}$ or less. Examination of two fish recaptured within a few weeks after deployment revealed a mesenteric growth around the tag, encapsulating and anchoring it inside the fish's abdomen.

\section{Recoveries}

A reward of $\$ 500$ was advertised at major fishing ports in the eastern and western North Pacific for return of the tag, fish, and the details of the recovery. In some cases, only the tag and recovery information were provided. If a fish was returned along with the tag, it was weighed and measured, the tag was removed, and the fish's size, sex, condition, and stomach contents were recorded. If malfunctioning sensors were identified at the time of data download, those data were excluded from the analyses.

\section{Analytical methods}

Estimated daily locations of the fish were generated using the light-level data recorded by the tag and the manufacturers' proprietary software (Hill and Braun, 2001; Lotek Wireless Inc., 2010). Locations were further refined using state-space models and SST (Sibert et al., 2003; Lam et al., 2008). Sea surface temperature was derived from water temperature recorded by each tag and represented the daily average of no fewer than 15 temperature readings at the surface or within the top isothermal layer of the water column. When accurate stalk temperature readings were available, the UKFSST model (Lam et al., 2008) was used to estimate locations. This model compares the SST derived from the tag with SST data from satellite imagery to improve location estimates. The satellite data used was a 5-day, blended SST product combining infrared and microwave measurements from a number of satellite platforms (Powell et al., 2008). For those time periods when the external temperature sensor had failed, precluding the use of SST, the KFtrack model (Sibert et al., 2003) was used to refine locations. For tracks estimated without SST correction, only locations within each 3-month period centered on the summer and winter solstices were used to determine rates of movements and integrate 
horizontal movements with oceanography. This method excludes days around the equinox where location estimation is difficult due to proximally equal day lengths at all latitudes. Using these methods, longitude root mean square error is estimated to be $0.5^{\circ}$, and latitude root mean square error for SSTcorrected tracks or time periods near the solstice is estimated to be $1.2^{\circ}$ (Hill and Braun, 2001; Lam et al., 2008). Although it was not possible to calculate exact errors for locations estimated throughout the track because the true position of the fish was unknown, light- and SST-based geolocation estimates derived using similar methods and validated with concurrent radio-positioning satellite tags or from known endpoint locations also estimate errors of this magnitude (Wilson et al., 2007; Boustany et al., 2010).

To investigate migratory behavior, daily swimming speeds were computed from the reliable location estimates. Daily speeds, computed as moving 5-day averages, were used to categorize the horizontal movements into two behavioral modes: 'residing' and 'non-residing'. Albacore were considered to be 'residing' when the daily speed was less than $40 \mathrm{~km}^{\text {day }}{ }^{-1}$ for three or more consecutive days. This threshold value was chosen because it captured the speeds associated with movements in the fishery areas along the coast where they are known to reside for several months (Clemens, 1961; Otsu and Uchida, 1963; Laurs et al., 1977) and for offshore areas with highly tortuous and confined movements.

Kernel density plots of all reliable locations were generated using the 'spatial analysis' extension of the Geographic Information System software ArCVIEW (Environmental Systems Research Institute, Inc.). The spatial analysis tool in ARCVIEW uses a quadratic kernel function (Silverman, 1986). The search radius used was $1.53^{\circ}$. To examine behavior of albacore within the fishery areas and offshore, five near-shore focal areas and four additional offshore focal areas were identified where high kernel densities and 'residing' behavior coincided. To minimize potential biases associated with tagging procedures, the first 30 days after tagging were eliminated from both kernel density and vertical and horizontal behavior analyses.

The archival tag data were temporally categorized as either daytime, nighttime or crepuscular and then summarized to quantify the percent of time spent at depth and ambient water temperature and to examine diurnal activity patterns. The crepuscular period was defined as each 60-min period centered on sunrise and sunset. The times of sunrise and sunset were determined using the tag manufacturers' software and generally corresponded to the inflection point of the light level intensity curve. Choice of the 60-min crepuscular period was validated by comparing the period centered on tag-derived sunrise and sunset times for deployment, recovery and SST-corrected locations, with twilight times determined for those locations using the NOAA astronomical calculator (http:// www.srrb.noaa.gov/highlights/sunrise/sunrise.html).

Statistical summaries of depths, temperatures and oceanographic indices associated with residing behavior were generated to characterize habitat use. Crepuscular readings were not included in the analyses to examine diurnal behavior because they generally reflected transitional behavior. Oceanographic features examined included depth of the mixed layer derived from the tag data, satellite-derived SST, and chlorophyll-a (Chl-a) concentrations. Five-day blended SST (Powell et al., 2008) and 8-day MODIS Chl-a data corresponding to residing locations were obtained from the NOAA Coastwatch website (http://coastwatch.pfeg.noaa.gov/ coastwatch/CWBrowserWW360.jsp).

To estimate the depth of the mixed layer, daily temperature-depth profiles were generated after binning data into $10-\mathrm{m}$ depth bins. For those bins with more than three temperature-depth readings, a mean temperature was calculated. The depth of the bottom of the mixed layer was defined by computing the second derivative of the binned temperature-depth profile and taking its local minimum prior to where the slope reached $0.03^{\circ} \mathrm{C} \mathrm{m}^{-1}$. Although the mixed layer depth (MLD) may have been less than $25 \mathrm{~m}$ in some areas, the lowest estimate that can be derived for MLD using this method is $25 \mathrm{~m}$. This daily average MLD was determined unless: (i) the maximum change in temperature for the day was less than $1.5^{\circ} \mathrm{C}$, representing days when the fish remained in relatively isothermal waters; or (ii) the maximum change in temperature with respect to depth (the slope) was less than $0.03^{\circ} \mathrm{C} \mathrm{m}^{-1}$, representing days when the temperature changes were too subtle to confidently establish a distinct MLD. Mixed layer depth was then smoothed using a 3-day running average. This method consistently provided reliable estimates of the bottom of the mixed layer based on temperature.

\section{RESULTS}

\section{Release and recovery statistics}

Twelve trips were conducted during the summer and fall between 2001 and 2006, resulting in 504 archival and 43 dummy tag releases (Fig. 1). The 15 Northwest Marine Technology tags and 43 dummy tags were all deployed in the southern fishery area along with 35 
Figure 1. Deployment locations of archival tagged albacore. In addition, 43 dummy tags were deployed in the southern area in 2003.

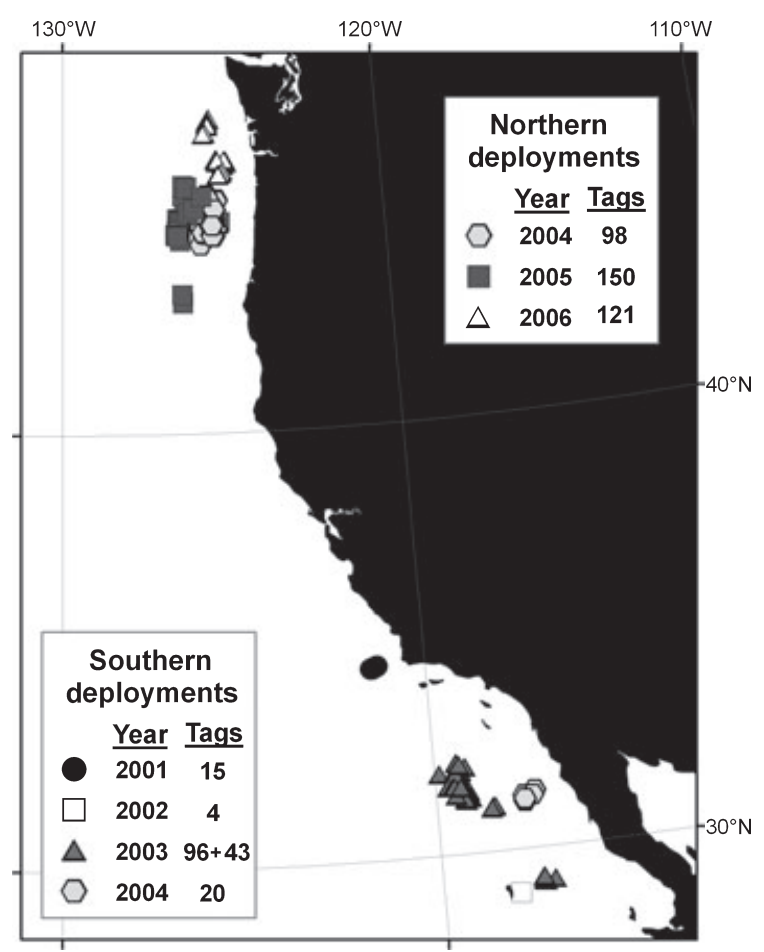

MK9s and 85 LTD2310s. In the northern fishery area, $173 \mathrm{MK} 9$ s and 196 LTD2310s were deployed.

The sizes of tagged albacore ranged from 57 to $110 \mathrm{~cm}$ FL (Fig. 2) and averaged $76.7 \pm 8.6 \mathrm{~cm}$ (mean \pm SD throughout, unless otherwise indicated). In the northern fishery area, tagged fish averaged $73.9 \pm 6.7 \mathrm{~cm}$ FL, whereas, the size of fish tagged in the southern area was significantly larger, averaging $82.4 \pm 9.4 \mathrm{~cm}$ FL $(D=0.526, P<0.001$, Kolmogo-
rov-Smirnov test). In both locations, the length distribution of tagged fish was bimodal.

Twenty archival tags and six dummy tags were recovered, resulting in a recovery rate of $4.8 \%$. The recovery rate of fish tagged in the southern fishery area was $9.6 \%$, whereas the recovery rate for fish tagged in the northern fishery area was $2.4 \%$. Times at liberty ranged from 63 to 753 days and averaged $357 \pm$ 142 days with no significant difference between the two tagging areas $(D=0.386, P=0.346$, Kolmogorov-Smirnov test). Deployment and recovery details for the 26 recaptured fish are shown in Table 1. Eighteen recoveries were provided by the U.S. sport fishing fleet, four by the U.S. commercial surface fleet, two by the Taiwanese longline fleet operating in the central North Pacific, one by a Mexican purse seine vessel and one by a Japanese pole-and-line vessel.

\section{Archival tag data recovery}

The archival-tagged albacore were at liberty for a combined total of 6541 days. Some tag failures, however, resulted in the loss of sensor data. The external temperature sensor of seven tags failed, one tag had a depth sensor failure, and one had a premature battery failure. Most failures occurred during the latter half of the deployments and made it impossible to determine reliable location estimates using SST correction for 787 of the 6541 days.

\section{Vertical and thermal habitat}

Depth and temperature summaries from the tag data for all fish are shown in Table 2. The depth range of the tagged albacore exceeded $1150 \mathrm{~m}$; however, only nine of the 20 fish dove deeper than $400 \mathrm{~m}$. With the exception of one fish that migrated to coastal Japan (see below), dives to greater than $400 \mathrm{~m}$ were always

Figure 2. Size distribution of tagged fish.

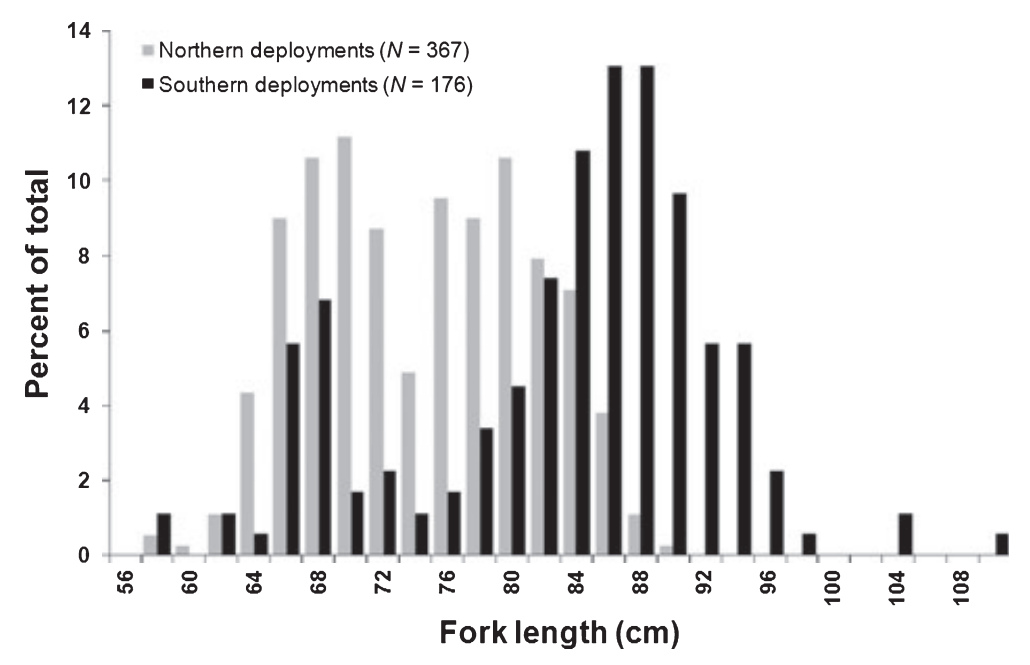

Published 2011. This article is a US Government work and is in the public domain in the USA., Fish. Oceanogr., 20:3, $157-173$. 
Table 1. Release and recovery statistics for 26 recaptured albacore. Asterisk indicates that the final location was not provided but was estimated from light level data as described in Methods.

\begin{tabular}{|c|c|c|c|c|c|c|c|c|c|c|}
\hline \multirow[b]{2}{*}{ Tag number } & \multirow[b]{2}{*}{ Type } & \multicolumn{4}{|l|}{ Release } & \multicolumn{3}{|l|}{ Recovery } & \multirow[b]{2}{*}{$\begin{array}{l}\text { Days at } \\
\text { liberty }\end{array}$} & \multirow[b]{2}{*}{$\begin{array}{l}\text { Net } \\
\text { movement } \\
(\mathrm{km})\end{array}$} \\
\hline & & Date & $\begin{array}{l}\text { Latitude } \\
\left({ }^{\circ} \mathrm{N}\right)\end{array}$ & Longitude & $\begin{array}{l}\text { Fork } \\
\text { length } \\
(\mathrm{cm})\end{array}$ & Date & $\begin{array}{l}\text { Latitude } \\
\left({ }^{\circ} \mathrm{N}\right)\end{array}$ & Longitude & & \\
\hline A00007 & DUMMY & $7 / 3 / 2003$ & 31.41 & -119.21 & 67 & $8 / 19 / 2004$ & 31.63 & -118.30 & 414 & 89 \\
\hline A00008 & DUMMY & $7 / 3 / 2003$ & 31.41 & -119.21 & 65.5 & $7 / 9 / 2004$ & 46.25 & -125.07 & 373 & 1724 \\
\hline A00013 & DUMMY & $7 / 4 / 2003$ & 31.36 & -119.18 & 79 & $8 / 25 / 2004$ & 31.47 & -118.15 & 419 & 98 \\
\hline A00021 & DUMMY & $7 / 5 / 2003$ & 31.33 & -119.17 & 67 & $8 / 30 / 2004$ & 31.88 & -118.60 & 423 & 82 \\
\hline A00033 & DUMMY & $7 / 6 / 2003$ & 31.24 & -119.19 & 62 & $7 / 27 / 2005$ & 31.62 & -118.82 & 753 & 55 \\
\hline A00034 & DUMMY & $7 / 6 / 2003$ & 31.27 & -119.22 & 66 & $7 / 7 / 2004$ & 31.82 & -117.98 & 368 & 132 \\
\hline A00052 & MK9 & $7 / 25 / 2003$ & 29.23 & -117.35 & 84 & $7 / 2 / 2004$ & 30.02 & -117.05 & 344 & 92 \\
\hline A00058 & MK9 & $7 / 27 / 2003$ & 29.27 & -117.35 & 89 & $10 / 18 / 2003$ & 32.32 & -119.18 & 84 & 381 \\
\hline A00067 & MK9 & $7 / 27 / 2003$ & 29.27 & -117.35 & 87 & $7 / 10 / 2004$ & 29.93 & -116.70 & 350 & 97 \\
\hline A00088 & LTD2310 & $11 / 7 / 2003$ & 31.87 & -119.42 & 81 & $8 / 6 / 2004$ & 31.38 & -117.82 & 274 & 161 \\
\hline A00096 & LTD2310 & $11 / 7 / 2003$ & 31.88 & -119.88 & 90 & $8 / 30 / 2004$ & 31.37 & -117.75 & 298 & 210 \\
\hline A00102 & LTD2310 & $11 / 7 / 2003$ & 31.90 & -119.45 & 86.5 & $8 / 27 / 2004$ & 30.93 & -117.73 & 295 & 195 \\
\hline A00120 & LTD2310 & $11 / 8 / 2003$ & 31.93 & -119.42 & 88 & $8 / 21 / 2004$ & 31.78 & -118.15 & 288 & 121 \\
\hline A00124 & LTD2310 & $11 / 8 / 2003$ & 31.90 & -119.33 & 87.5 & $8 / 27 / 2004$ & 30.92 & -117.70 & 294 & 190 \\
\hline A00132 & LTD2310 & $11 / 8 / 2003$ & 31.85 & -119.45 & 88 & $8 / 16 / 2004$ & 31.35 & -117.43 & 283 & 199 \\
\hline A00146 & LTD2310 & $11 / 10 / 2003$ & 32.00 & -119.18 & 81.5 & $8 / 20 / 2004$ & 31.53 & -117.57 & 285 & 161 \\
\hline A00151 & LTD2310 & $6 / 30 / 2004$ & 44.71 & -125.76 & 66 & $5 / 27 / 2006$ & 30.30 & -144.58 & 697 & 2295 \\
\hline A00166 & LTD2310 & $7 / 1 / 2004$ & 44.53 & -125.63 & 65 & $9 / 1 / 2005$ & 45.53 & -125.97 & 428 & 115 \\
\hline A00170 & LTD2310 & $7 / 1 / 2004$ & 44.52 & -125.62 & 64 & $9 / 19 / 2005$ & 45.78 & -126.50 & 446 & 157 \\
\hline A00173 & LTD2310 & $7 / 1 / 2004$ & 44.52 & -125.62 & 65 & $9 / 1 / 2004$ & 45.77 & -126.18 & 63 & 146 \\
\hline A00202 & LTD2310 & $8 / 12 / 2004$ & 31.23 & -117.67 & 82.5 & $7 / 5 / 2005$ & 30.27 & -117.67 & 328 & 107 \\
\hline A00226 & LTD2310 & $9 / 13 / 2004$ & 45.23 & -125.21 & 75 & $8 / 10 / 2005$ & 32.00 & -118.33 & 332 & 1585 \\
\hline A00230 & MK9 & $9 / 13 / 2004$ & 45.03 & -125.28 & 78 & $12 / 6 / 2005$ & 33.70 & -167.83 & 450 & 3816 \\
\hline A00468 & LTD2310 & $8 / 6 / 2006$ & 46.05 & -124.97 & 75 & $8 / 21 / 2007$ & 32.37 & -118.25 & 381 & 1625 \\
\hline A00480 & MK9 & $8 / 7 / 2006$ & 46.10 & -124.87 & 70 & $6 / 29 / 2007$ & 32.00 & -117.92 & 327 & 1676 \\
\hline A00483 & MK9 & $8 / 7 / 2006$ & 46.07 & -124.87 & 77 & $5 / 27 / 2007$ & $32.5 *$ & $140.1^{*}$ & 294 & $7822 *$ \\
\hline
\end{tabular}

Table 2. Data summaries from all recovered tags. Standard deviations are by fish. Crepuscular periods were not included in analysis.

\begin{tabular}{|c|c|c|c|c|c|c|c|}
\hline & \multirow{2}{*}{$\begin{array}{l}\text { Number of } \\
\text { fish }\end{array}$} & \multicolumn{2}{|l|}{ Overall } & \multicolumn{2}{|l|}{ Day } & \multicolumn{2}{|l|}{ Night } \\
\hline & & Range & Mean \pm SD & Range & Mean \pm SD & Range & Mean \pm SD \\
\hline Depth (m) & 20 & $0-1185$ & $40 \pm 9.6$ & 0-811 & $59 \pm 14.3$ & $0-1045$ & $20 \pm 6.2$ \\
\hline Ambient water temperature $\left({ }^{\circ} \mathrm{C}\right)$ & 17 & $3.3-22.7$ & $16.6 \pm 0.6$ & $4.5-22.7$ & $15.7 \pm 0.6$ & $3.3-22.3$ & $17.5 \pm 0.9$ \\
\hline Internal temperature $\left({ }^{\circ} \mathrm{C}\right)$ & 20 & $11.1-30.3$ & $20.7 \pm 0.9$ & $11.2-30.3$ & $21.0 \pm 1.0$ & $11.1-29.8$ & $20.5 \pm 1.1$ \\
\hline Speed $\left(\mathrm{km} \mathrm{day}^{-1}\right)$ & 20 & 5-195 & $42 \pm 14.8$ & & & & \\
\hline Mixed layer depth (m) & 17 & $25-275$ & $51 \pm 12.4$ & & & & \\
\hline Time spent in mixed layer $(\%)$ & 17 & 44-90 & $71 \pm 5.9$ & $10-87$ & $49 \pm 9.6$ & $51-100$ & $91 \pm 4.6$ \\
\hline Sea surface temperature $\left({ }^{\circ} \mathrm{C}\right)$ & 17 & $11.9-22.3$ & $17.6 \pm 0.9$ & & & & \\
\hline
\end{tabular}

brief; the maximum duration of any dive below $400 \mathrm{~m}$ in the eastern Pacific was $32 \mathrm{~min}$. In general, albacore exhibited a diurnal diving pattern, spending more time near the surface at night than during the day (Fig. 3a).

The average SST for each deployment was $17.6 \pm$ $0.9^{\circ} \mathrm{C}$, and SSTs encountered ranged from 11.9 to $22.3^{\circ} \mathrm{C}$. The ambient temperature range was greater than the SST range, with lower temperatures during the day due to the diurnal diving behavior (Table 2, Fig. 3b). Peritoneal temperatures were consistently higher than ambient water temperatures by $3.9 \pm 0.8^{\circ} \mathrm{C}$ on average $(t=-20.04, P<0.001$, paired $t$-test $)$.

Published 2011. This article is a US Government work and is in the public domain in the USA., Fish. Oceanogr., 20:3, 157-173. 
Figure 3. (a) Mean percentage of time spent at depth, by fish. The solid line is the mean mixed layer depth with dashed lines representing the standard deviation. Percentages shown above the dashed lines are the percentages of time spent above the mixed layer depth. (b) Mean percentage of time spent at temperature, by fish.
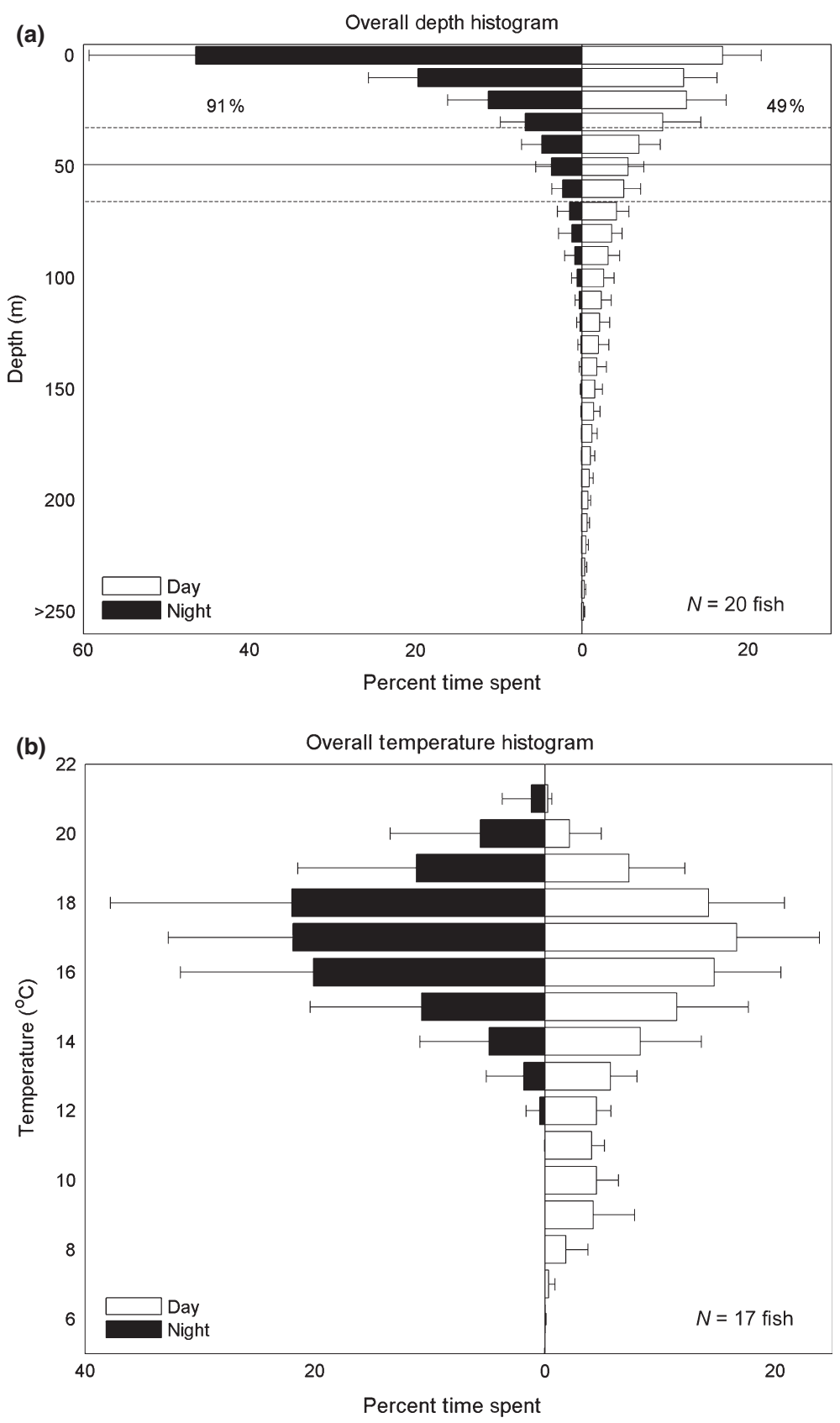

The average MLD for fish was $51 \pm 12 \mathrm{~m}$ but varied geographically (see below). Tagged albacore spent nearly all of their time (91\%) in the mixed layer at night in comparison with $49 \%$ of their time in the mixed layer during the day (Table 2, Fig. 3a).

\section{Horizontal movements}

For all fish, the average rate of movement based on reliable location estimates was $42 \pm 14.8 \mathrm{~km} \mathrm{day}^{-1}$ (Table 2). Eighteen of the 20 recaptured fish were at liberty for at least 9 months (Table 1) and demon- strated extensive horizontal movements. The movements of these fish were classified into five different migration patterns (Fig. $4 \mathrm{a}-\mathrm{e}$ ):

1 North-Offshore-North: migrating west from the northern fishery area to offshore areas between $150^{\circ} \mathrm{W}$ and $180^{\circ}$ during the winter and returning to the northern fishery area the following summer $(N=4)$; 2 North-Offshore-South: migrating west and south from the northern fishery area during the winter then into the southern fishery area the following summer $(N=3)$;

Published 2011. This article is a US Government work and is in the public domain in the USA., Fish. Oceanogr., 20:3, 157-173. 
Figure 4. Migration types colored by month. (a) North-offshore-north; (b) North-offshore-south; (c) South-offshore-south; (d) Baja; (e) Trans-Pacific. Legends shown in panel (e).

(a) $180^{\circ} 170^{\circ} \mathrm{W} 160^{\circ} \mathrm{W} 150^{\circ} \mathrm{W} 140^{\circ} \mathrm{W} 130^{\circ} \mathrm{W} 120^{\circ} \mathrm{W} \quad 110^{\circ} \mathrm{W} \quad 100^{\circ} \mathrm{W}$

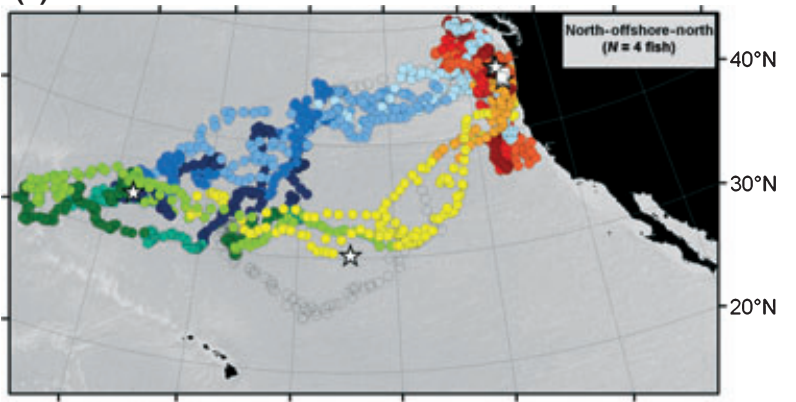

(b) $180^{\circ} 170^{\circ} \mathrm{W} 160^{\circ} \mathrm{W} 150^{\circ} \mathrm{W} 140^{\circ} \mathrm{W} 130^{\circ} \mathrm{W} 120^{\circ} \mathrm{W} \quad 110^{\circ} \mathrm{W} \quad 100^{\circ} \mathrm{W}$

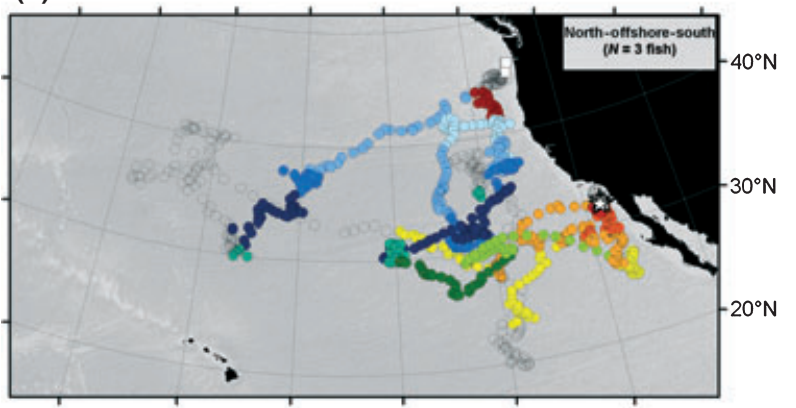

(c) $180^{\circ} \quad 170^{\circ} \mathrm{W} 160^{\circ} \mathrm{W} 150^{\circ} \mathrm{W} 140^{\circ} \mathrm{W} 130^{\circ} \mathrm{W} 120^{\circ} \mathrm{W} 110^{\circ} \mathrm{W} \quad 100^{\circ} \mathrm{W}$

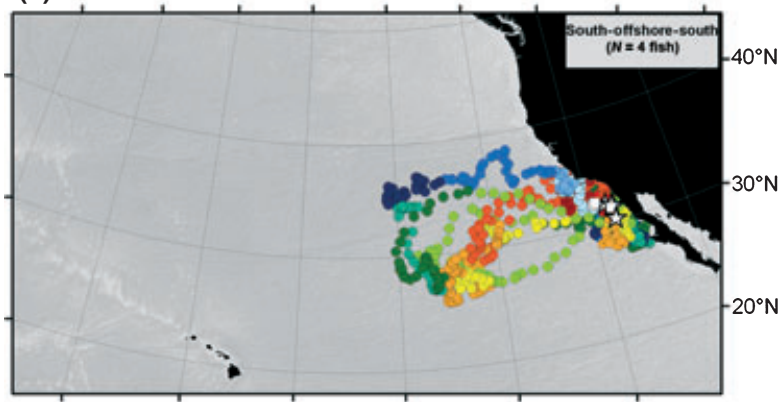

3 Trans-Pacific: migrating from the northern fishery area into the central North Pacific during the winter then into the western Pacific the following spring $(N=1)$;

4 South-Offshore-South: migrating west from the southern fishery area to offshore areas between 130 and $140^{\circ} \mathrm{W}$ during the winter and returning to the southern fishery area the following summer $(N=4)$;

5 Baja: overwintering along the Baja peninsula, Mexico, and returning to the southern fishery area during the following summer $(N=6)$.

Seasonality of movements was more consistent than migration paths. During the summer and fall the fish remained near the North American coast within the main fishery areas. Departure from the fishery areas usually occurred during October or November, when (d) $180^{\circ} 170^{\circ} \mathrm{W} 160^{\circ} \mathrm{W} 150^{\circ} \mathrm{W} 140^{\circ} \mathrm{W} 130^{\circ} \mathrm{W} 120^{\circ} \mathrm{W} \quad 110^{\circ} \mathrm{W} \quad 100^{\circ} \mathrm{W}$

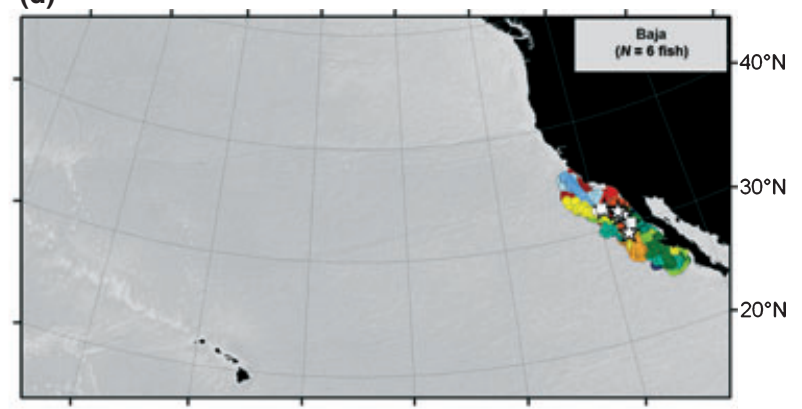

(e) $130^{\circ} \mathrm{E} 140^{\circ} \mathrm{E} 150^{\circ} \mathrm{E} \quad 170^{\circ} \mathrm{E} \quad 170^{\circ} \mathrm{W} \quad 150^{\circ} \mathrm{W} \quad 130^{\circ} \mathrm{W} \quad 110^{\circ} \mathrm{W}$

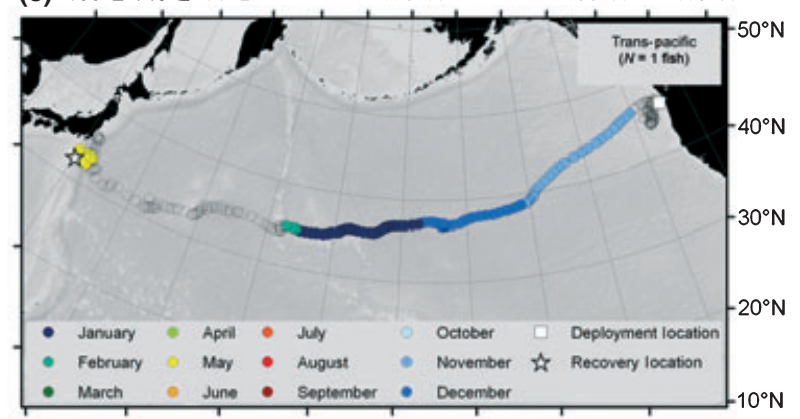

the fish migrated either west or south. For those fish that returned to the same fishery areas in the following spring, the return trip usually began in April or May with arrival into the main fishery areas in June or July. Albacore moved significantly more rapidly into or out of the fishery areas $\left(90 \pm 24 \mathrm{~km} \mathrm{day}^{-1}\right)$ and slowed their travel in areas offshore or south during the intervening months $\left(24 \pm 8 \mathrm{~km} \mathrm{day}^{-1} ; t=62.16\right.$, $P<0.001$, two-sample $t$-test). Monthly rates of movement reflect the overall timing of the onshoreoffshore and north-south migrations (Fig. 5).

Habitat preferences and behaviors in focal areas

Nine specific focal areas of high use were identified where there was resident behavior by one or more tagged fish (Fig. 6). These nine focal areas accounted

Published 2011. This article is a US Government work and is in the public domain in the USA., Fish. Oceanogr., 20:3, $157-173$. 
Figure 5. Monthly mean speeds by fish grouped by migration type where offshore-onshore fish includes north-offshore-north, north-offshore-south, and south-offshore-south migration patterns.

Figure 6. Kernel density composite created from all high-quality locations showing focal areas of high use. Focal areas are labeled as numbered in the text.
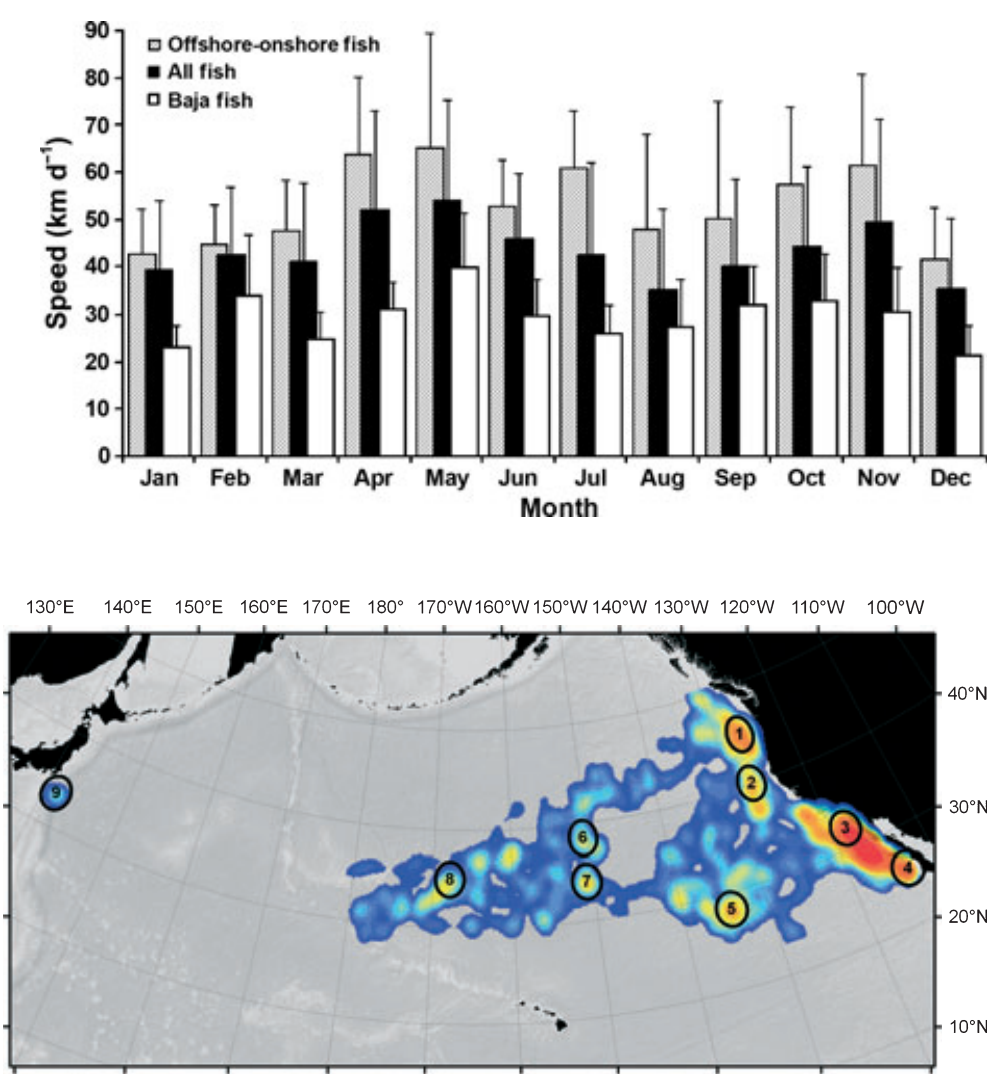

for $47 \%$ of all residing days for all fish throughout the tracks. Five coastal focal areas were identified off North America and Japan. Fish that migrated offshore traveled to four additional focal areas in the midPacific.

Tag data revealed that water temperatures and MLD within each focal area during the typical months of residence differed (Table 3 ). Correspondingly, swimming depth and percent time spent below the MLD also differed.

Four specific focal areas were examined in greater detail because they contained the greatest times of residency for two or more albacore and they represented a coastal and corresponding offshore area important to the U.S. commercial (areas one and seven) and recreational (areas three and five) albacore fisheries. Limited data precluded in-depth analysis of all focal areas. Albacore resided in focal area one from July through September. During those months, focal area one was characterized by cool SST $\left(17.4 \pm 1.3^{\circ} \mathrm{C}\right)$, high Chl-a $\left(0.43 \pm 0.44 \mathrm{mg} \mathrm{m}^{-3}\right)$ and a shallow MLD $(25 \pm 0 \mathrm{~m})$. In this focal area, fish spent the majority of time in the upper $25 \mathrm{~m}$ of the water column (Fig. 7a-c). In the winter, two fish moved offshore from focal area one into focal area seven. This offshore focal area was characterized by cooler surface temperatures $\left(16.7 \pm 0.7^{\circ} \mathrm{C}\right)$, lower Chl-a levels $\left(0.12 \pm 0.02 \mathrm{mg} \mathrm{m}^{-3}\right)$ and a deeper MLD $(81 \pm 12 \mathrm{~m})$. Fish in this area tended to dive to greater depths, particularly during the day (Fig. 8a-c). During July and August, albacore resided in the southern fishery area, focal area three. This area was characterized by warmer surface water $\left(18.9 \pm 1.4^{\circ} \mathrm{C}\right)$, moderate levels of Chl-a $\left(0.32 \pm 0.29 \mathrm{mg} \mathrm{m}^{-3}\right)$ and a shallow MLD $(25.3 \pm 0.9 \mathrm{~m})$. The mean swimming depth of fish residing in this area was greater than in the northern coastal area due to deeper daytime diving (Fig. 9a-c). During the spring, three fish migrated from focal area three to focal area five, an offshore area midway between Baja and Hawaii, characterized by the warmest water $\left(20.7 \pm 0.6^{\circ} \mathrm{C}\right)$, the lowest Chl-a concentrations $\left(0.07 \pm 0.02 \mathrm{mg} \mathrm{m}^{-3}\right)$ and a relatively deep MLD $(83 \pm 37 \mathrm{~m})$, like that of the other offshore focal area. In this area, fish demonstrated a markedly different diving behavior, spending most of the time below the MLD during the day (Fig. 10a-c). Bonferroni-corrected pairwise comparisons demonstrated that MLD, SST, Chl-a and mean daytime swimming depth differed significantly among all regions ( $P<0.05$, Wilcoxon rank-sum test), with the exception of MLD between focal areas one and three and MLD between focal areas five and seven.

Published 2011. This article is a US Government work and is in the public domain in the USA., Fish. Oceanogr., 20:3, $157-173$. 


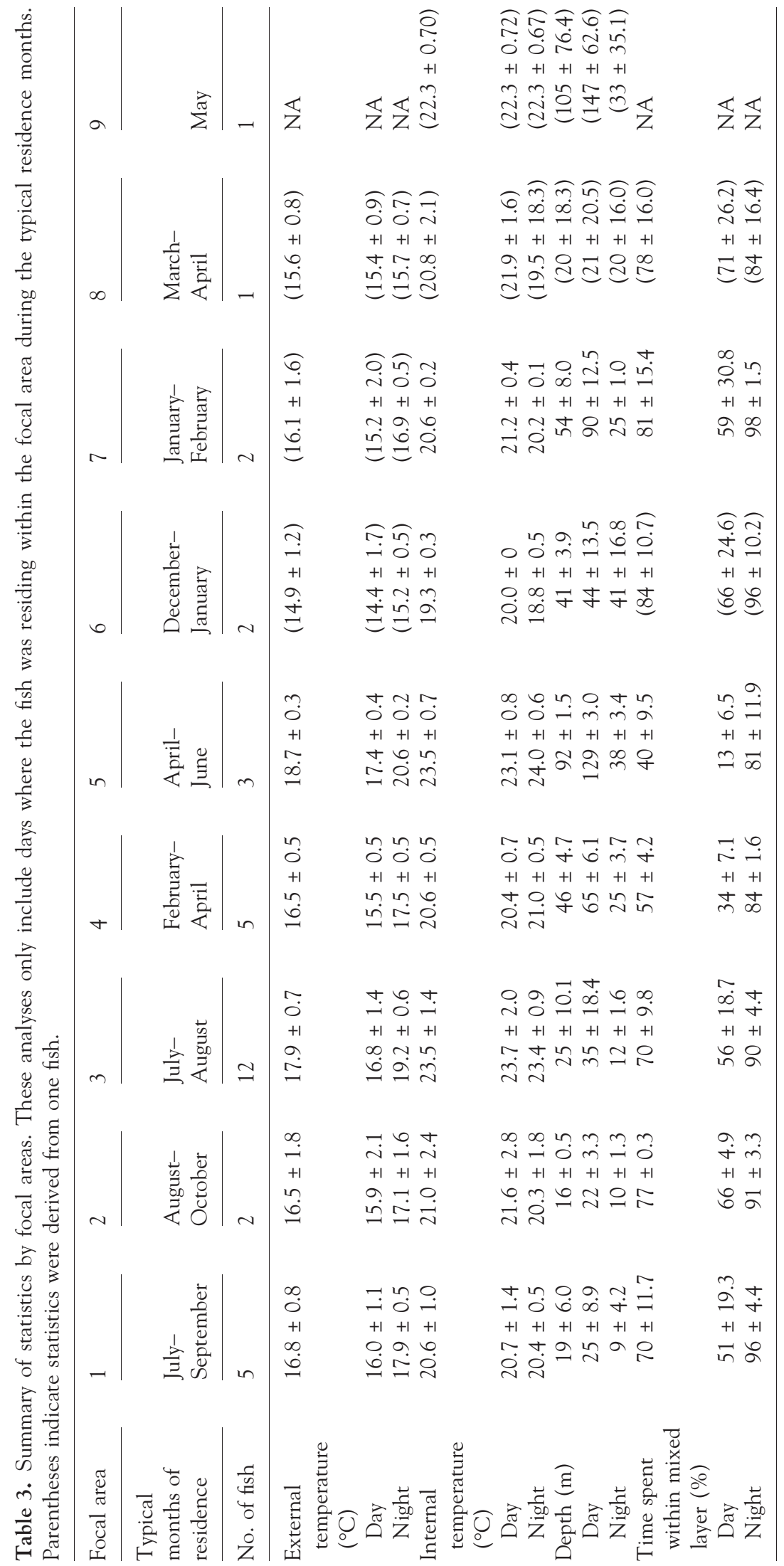

Published 2011. This article is a US Government work and is in the public domain in the USA., Fish. Oceanogr., 20:3, 157-173. 
Figure 7. Behavior patterns for fish residing in focal area one, July-September. (a) One week of time series data for one representative fish. Night and crepuscular periods are represented with dark gray and light gray, respectively. The dashed line denotes the daily calculated MLD. (b) Relative time spent at depth by local time of day for all observations. (c) Frequency histogram of percent time spent at depth for all observations. The solid line is the mean MLD with dashed lines representing the standard deviation. Percentages shown above the dashed lines are the percentages of time spent above the MLD.
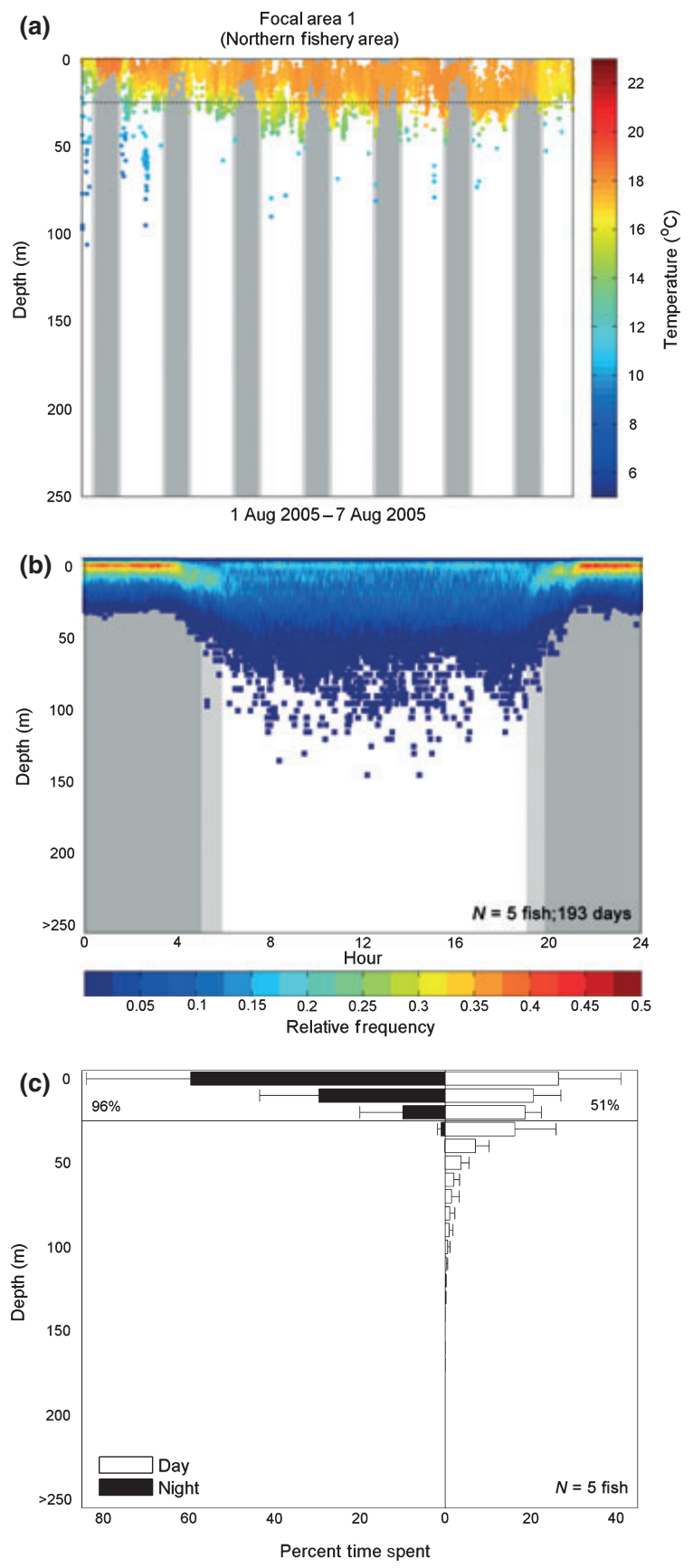

Figure 8. Behavior patterns for all fish residing in focal area seven, January and February. See Fig. 7 legend for details.
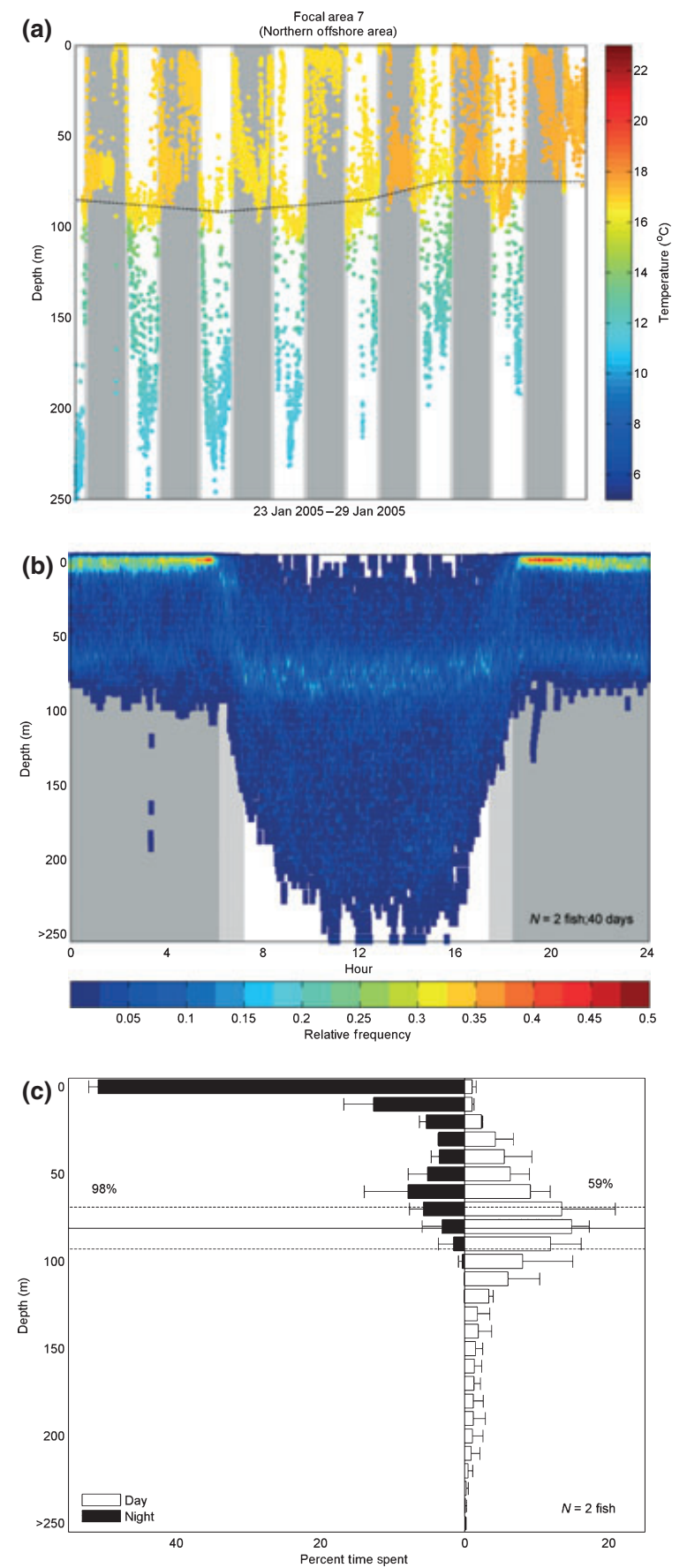

\section{DISCUSSION}

The results of this study demonstrate the broad range of juvenile albacore behavior in the eastern North Pacific. Previously, juvenile albacore were believed to

Published 2011. This article is a US Government work and is in the public domain in the USA., Fish. Oceanogr., 20:3, $157-173$. 
Figure 9. Behavior patterns for all fish residing in focal area three, July-August. See Fig. 7 legend for details.
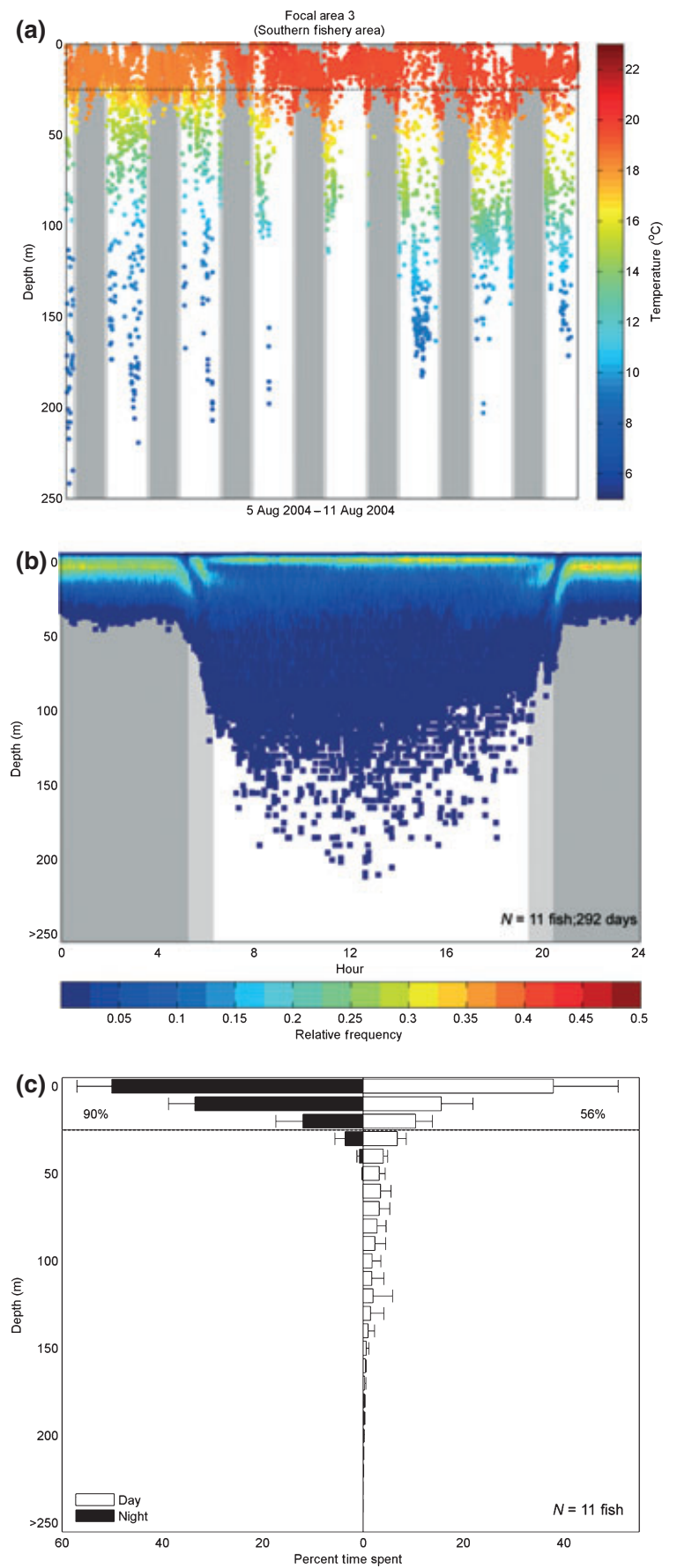

be predominantly surface dwelling; however, the results presented here reveal that juvenile albacore frequently inhabit depths well below the mixed layer. Detailed diurnal behavior patterns are evident from the fine-scale resolution of the archival tag data. While conventional tagging has demonstrated that
Figure 10. Behavior patterns for all fish residing in focal area five, April-June. See Fig. 7 legend for details.
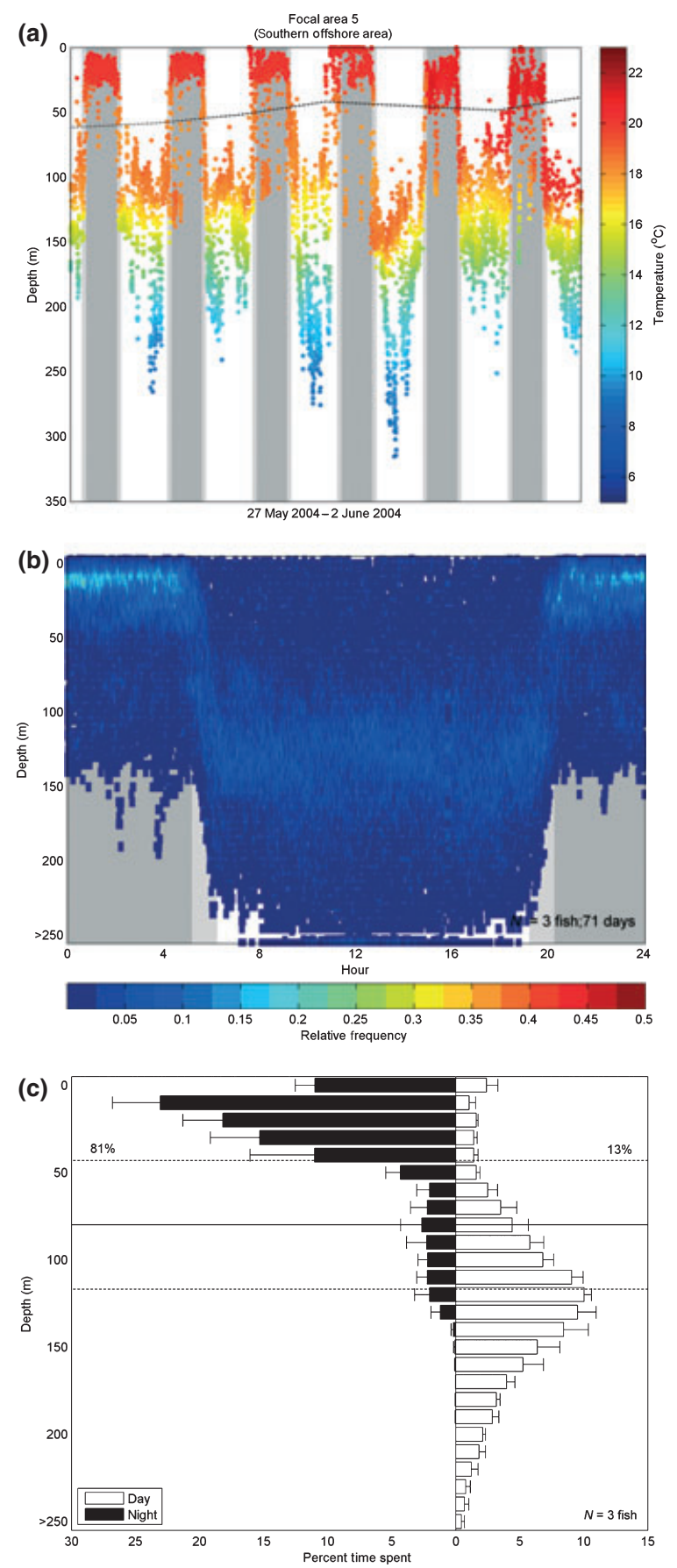

albacore undertake long-range migrations, the results of this study provide detailed movement paths and rates, and reveal the distinct seasonality of their migratory movements into and out of the Eastern Pacific commercial and recreational fishing grounds. Also, resident behavior of juvenile albacore at specific

Published 2011. This article is a US Government work and is in the public domain in the USA., Fish. Oceanogr., 20:3, $157-173$. 
areas of importance along the migration routes has been illustrated, along with regional and temporal variation in their vertical behavior. Examining the detailed vertical and horizontal movements of albacore provides insights on their availability to fisheries harvesting albacore in the North Pacific.

\section{Seasonal movement patterns}

Seasonal presence of juvenile albacore along the North America coast in summer and fall months is well known from fishery data (e.g., Clemens, 1961; Pearcy, 1973; Childers and Betcher, 2010) as is their presence in the NPTZ during winter and spring months (e.g., Laurs and Nishimoto, 1979; Polovina et al., 2001). Fishery and conventional tagging data have also provided information on their movements throughout the North Pacific and in the Western Pacific once they recruit to the Japanese fisheries (Otsu and Uchida, 1963; Kimura et al., 1997). Less is known about details of the movements of fish after they depart or before they enter the Eastern Pacific fishery areas. In this study we describe five distinct migration patterns for juvenile albacore caught on the eastern North Pacific fishing grounds.

Previous studies have suggested a range of potential migratory patterns in association with the southern fishery based on conventional tag and catch data. Based on the occurrence of a few albacore taken off the Baja Peninsula of Mexico in the winter months, Clemens (1961) postulated that some albacore may overwinter near Guadalupe Island, Mexico, or farther south rather than undertake a westward migration to the central or western North Pacific. Conventional tag returns and differences in size compositions of fish caught in the commercial fisheries north and south of $40^{\circ} \mathrm{N}$ led Laurs and Lynn (1977) to suggest two distinct patterns of migration into the North America coastal surface fisheries from offshore transition zone waters: one population that follows a warm water front in late spring and summer out of the transition zone and northward into the northern fishery area, and a second population that approaches the coast within the southern part of the transition zone and comprises the fish taken in the southern fishery area off southern California and Northern Baja California, Mexico.

The current study now provides tracks of the movements of a distinct group of fish that remained along the Baja peninsula without migrating westward over the winter, supporting Clemens (1961) hypothesis that albacore overwinter off Baja. The estimated locations show that a portion of the population can be found within a fairly narrow band along the coast of Baja reaching as far south as Magdalena Bay by March and April, before returning northward to reenter the U.S. sport fishery area during the summer.

Tagged albacore that migrated offshore from the fishery areas showed seasonality in their migrations as well; however, given the broad range of movements (four offshore migration patterns) there was variation in the timing of departures and returns to the fishery areas. For example, of the four albacore that remained in the southern area but migrated to focal area five offshore, three left the coastal area in the spring and returned in July after only a couple of months. In contrast, the fourth fish departed the coast in December and returned in April. The former three fish were all tagged in the same location on two successive days and may have been members of the same school, whereas the fourth fish was tagged the following year. This difference highlights the plasticity of juvenile albacore migration; factors that may affect migration timing and routes include environmental variability and changes in prey availability, among others. In the Western Pacific, Kimura et al. (1997) suggested that migration of albacore is affected by El Niño conditions with a latitudinally broader migratory route during El Niño years than during non-El Niño years, and by greaterthan-average meandering of the Kuroshio Current resulting in a more eastward migratory pathway.

Seasonality of the north-offshore-north migrations was more consistent with respect to their departure and arrival times: all four fish departed in October and returned in May or June. When returning to the coastal areas from the NPTZ, albacore changed direction from their farthest westward point during March or April. One of the fish, at liberty for 697 days, was tracked out of the northern fishery area on two successive seasons following nearly the same path each time. In contrast, juvenile albacore in the Western Pacific migrate west into the coastal Japanese fisheries in late winter, arriving near shore in late February or March and departing the coast eastward for offshore waters of the Kuroshio Current Extension around May and June (Otsu and Uchida, 1963). An albacore tagged with an archival tag off Japan migrated east as far as $160^{\circ} \mathrm{W}$ before turning back toward Japan in October (Uosaki, 2006). In the Eastern Pacific, calculated daily rates of movement, while approximate as they are based on the light- and SST-based geolocations, clearly demonstrate greater movement rates when approaching the coast than during other parts of the migrations. Similarly, Otsu and Uchida (1963) concluded from conventional tagging data that movement rates between fishery areas were higher than movement rates within a fishery area. Oceanographic conditions may have influenced the timing of migrations; 
however, additional tag recoveries over a number of seasons will be needed to examine the interannual variability in departure and arrival times in greater detail.

\section{Habitat use}

The broad spatial scope of this study provides complete, in-depth information on the various habitats that juvenile albacore exploit in the eastern North Pacific. Albacore exhibit surface dwelling behavior in the near-shore fishery areas in the northeastern Pacific (e.g. Fig. 7), where MLDs are shallow and Chl-a concentrations are high. When these fish move offshore or south in the winter months and exhibit residency behavior in other areas, they tend to exploit deeper waters (e.g., Fig. 8). In focal areas four, five, seven and nine, juvenile albacore spent a relatively large amount of time below $100 \mathrm{~m}$ during the day. Several past studies in focal areas one and three, and in the NPTZ, which encompasses focal areas six and eight, used data from the surface fisheries to estimate the oceanographic preferences of albacore tuna (Pearcy, 1973; Laurs et al., 1984; Polovina et al., 2001). In this study, we show that albacore in those areas spend less than $50 \%$ of their time below the mixed layer during the day. However, in focal areas five and seven, albacore spend relatively little time near the surface during the day. From April through June, focal area five is characterized by a deep, weaklydefined MLD and low Chl-a levels where albacore spent much more of their time deeper in the water column (Table 3, Fig. 10). Lower Chl-a levels and less cloud cover allow light to penetrate deeper in the water column in comparison to in focal areas one and three. The additional light levels at depth may allow fish to forage successfully in deeper waters. Decreased levels of Chl- $a$ also indicate less productivity in the top $50 \mathrm{~m}$ of the water column, which may persuade albacore to forage at greater depths.

The patterns of habitat-use exhibited by North Pacific albacore, particularly for the fish caught and tagged in the southern fishery area, are similar to those observed for juvenile bluefin tuna studied with archival tags in the eastern North Pacific (Boustany et al., 2010). Both are temperate tunas that spend a significant part of their juvenile life in the rich waters of the California Current. Of 146 juvenile bluefin studied off Northern Baja California, Mexico, all but 17 overwintered along the U.S. and Mexico coasts and showed migration patterns similar to the six albacore in the present study that overwintered along Baja. Bluefin inhabited the same focal areas off Southern California and Northern Baja California, Mexico (focal area three), during the summer months and off Southern Baja (focal area four) during the winter months. Seven of the juvenile bluefin migrated north and west into the NPTZ and eventually to the Western Pacific following roughly the same route as the albacore that was recaptured off Japan in the present study (Boustany et al., 2010). Juvenile bluefin in the northeast Pacific are also known to be primarily surface-dwelling (Marcinek et al., 2001; Domeier et al., 2005; Kitagawa et al., 2007). Similarities in their physiological and ecological demands and movement patterns suggest that juvenile bluefin and albacore may be exploiting the same resources in the California Current and NPTZ ecosystems. Indeed, a study of bluefin and albacore feeding habits from samples collected off Southern California in the late 1960s identified Northern anchovy as the dominant prey for both bluefin and albacore (Pinkas et al., 1971). Further support for this idea may be obtained from future studies of juvenile bluefin and albacore biology and ecology in the California Current and in other parts of their range.

\section{Fishery interactions and implications}

U.S. commercial pole-and-line and troll fisheries target albacore in surface waters. In the southern fishery area, both bluefin and albacore support a lucrative U.S. recreational fishery that rivals the commercial fisheries in terms of economic value (Holts, 1985). The tag data reveal that albacore tend to utilize the surface waters more in these coastal areas than in offshore areas. Since albacore are primarily visual predators (Murphy, 1959) and are known to be actively feeding at the surface while in the coastal areas, they are susceptible to surface fishing gears, thus supporting the troll and pole-and-line fisheries. For the years covered in this study, albacore returned to the northern fishery area in May or June; however, fishing usually commences in the northern fishery area during July (Clemens, 1961). While the U.S. albacore fisheries operate near-shore in summer and fall, the nearshore albacore fisheries in Japan operate in the late winter and spring.

Upon their departure from the coastal region, vertical distribution information obtained from tagged fish indicates that juvenile albacore tend to exploit deeper waters in offshore areas south of the NPTZ, but still rarely dive below $250 \mathrm{~m}$. Therefore, while offshore, they may be susceptible to longline gear, especially shallow-set longline gear used to target swordfish, the average depth of which is roughly $60 \mathrm{~m}$ (Bigelow et al., 2006). Deep-diving behavior in focal areas five and seven may have resulted in relatively

Published 2011. This article is a US Government work and is in the public domain in the USA., Fish. Oceanogr., 20:3, 157-173. 
low catches in those regions by the U.S. albacore surface fisheries (Stocker, 2005), and historically those areas have not been areas of high effort for the surface fleet. U.S., Japanese and Taiwanese tuna longline fisheries that operate in the lower latitudes near focal area five, also catch albacore (Okamoto and Bayliff, 1999; Stocker, 2005); however, typically these fisheries catch larger, older albacore using deep-set tuna gear, rather than the juveniles studied here.

\section{Future considerations}

Oceanography plays an important role in albacore migration. However, multi-year tracks and data from other age classes of fish are needed to understand the influence of oceanographic parameters on migratory movements. Further tagging work with long-term deployments can help explain whether fish tend to remain in the eastern North Pacific for several seasons before migrating into the Western Pacific or migrate to subtropical regions where adult fish are taken in longline fisheries. In addition, while these data suggest limited mixing between the northern versus southern fishery areas in the Eastern Pacific, genetics and otolith microchemistry studies (Cadrin et al., 2005) may provide more conclusive evidence regarding stock structure in the eastern Pacific.

Further examinations of the feeding habits of albacore will help discern the importance of prey availability with regards to albacore migration. In near-shore areas, stomach content data reveal that albacore feed on a variety of small pelagic fish, cephalopods and crustaceans, which are typically encountered in the productive California Current waters (Pinkas et al., 1971; Glaser, 2010). While not the dominant prey, organisms associated with the deep scattering layer (DSL) were also found in the stomachs (Pinkas et al., 1971; Glaser, 2010). It is possible that albacore are foraging in association with the DSL in the offshore areas where surface waters tend to be more oligotrophic, although scant stomach content data for albacore collected offshore are available. Quantification of feeding episodes from peritoneal temperatures recorded by the tags is underway and will help to determine the importance of these offshore areas as foraging grounds.

Diurnal diving behavior in the offshore areas may result in predatory interactions. For, example focal area five has recently been characterized as an important foraging area for a number of other large pelagic predators (e.g., white sharks, Carcharodon carcharias, from California and Mexico) between April and July (Nasby-Lucas et al., 2009; Jorgensen et al., 2010). In this area, white sharks exhibit oscillatory diving behavior to depths of $200-400 \mathrm{~m}$, and it is speculated that the two species may be interacting, since tuna are known prey of white sharks (Fergusson et al., 2000). By conducting comprehensive oceanographic and ecological studies in some of the identified areas of importance, the role of juvenile albacore in the pelagic ecosystem can be better understood.

\section{CONCLUSIONS}

Analysis of data collected from archival tags deployed in North Pacific albacore has revealed new details of the migratory habits of this commercially important species. Some juvenile albacore that utilize the California Current along the west coast of North America venture out to the central North Pacific during the fall and winter months, whereas others remain along the coast of Baja California, Mexico, or transit to the Western Pacific. During the day and in specific areas, fish dive repeatedly below the mixed layer, whereas in other areas they remain predominantly in the upper mixed layer, particularly at night. Juvenile albacore show a wide range of horizontal and vertical movements that are season- and region-specific and are likely linked to oceanographic conditions and forage availability.

These data provide evidence to support previous ideas on albacore movements and biology. Further deployments will provide additional details of the migration patterns and life history strategies of North Pacific albacore as they mature, which in turn can be used to properly manage the stock and keep it sustainable for the various international fisheries that harvest this species.

\section{ACKNOWLEDGEMENTS}

The release and recapture of tagged fish could not have been achieved without the cooperation of commercial and sport fishermen that target albacore. We greatly appreciate the collaboration with the American Fishermen's Research Foundation (AFRF), particularly their assistance with funding and vessel charters. The Tagging of Pacific Predators (TOPP) Program, the Inter-American Tropical Tuna Commission (IATTC), and Monterey Bay Aquarium provided invaluable assistance with deployments and training during the early stages of the study. We thank the captains and crew of all of the chartered vessels who helped with deployments: Her Grace, Shogun, Jody H, Judy S, Hans Halvor, Royal Dawn, Cinda S and Holly H. Assistance in recovering tags was received from the U.S. commercial albacore surface fleet, the San Diego sport

Published 2011. This article is a US Government work and is in the public domain in the USA., Fish. Oceanogr., 20:3, $157-173$. 
fishing fleet, the IATTC, TOPP, the Taiwan tuna longline observer program, and the South Pacific Commission. We thank Anders Nielsen and Chi (Tim) Lam for assisting with the state-space models and Dave Foley for help extracting the oceanographic data. We also thank Heidi Dewar and Steve Teo for valuable discussions and contributions and three anonymous reviewers for their constructive critiques that helped improve the manuscript.

\section{REFERENCES}

Arnold, G. and Dewar, H. (2001) Electronic tags in marine fisheries research: a 30-year perspective. In: Electronic Tagging and Tracking in Marine Fisheries. J.R. Sibert \& J.L. Nielsen (eds) Dordrecht: Kluwer Academic Publishers, pp. 7-64.

Bigelow, K., Musyl, M.K., Poisson, F. and Kleiber, P. (2006) Pelagic longline gear depth and shoaling. Fish. Res. 77:173183.

Block, B.A., Dewar, H., Blackwell, S.B. et al. (2001) Electronic tags reveal migratory movements, depth preferences and thermal biology of Atlantic bluefin tuna. Science 293:1310 1314.

Boustany, A.M., Matteson, R., Castleton, M., Farwell, C. and Block, B.A. (2010) Movements of pacific bluefin tuna (Thunnus orientalis) in the Eastern North Pacific revealed with archival tags. Prog. Oceanogr. 86:94-104.

Brock, V.E. (1943) Contribution to the biology of the albacore (Germo alalunga) of the Oregon coast and other parts of the North Pacific. Stanford Ichthyol. Bull. 2:199-248.

Cadrin, S.X., Friedland, K.D. and Waldman, J. (eds) (2005) Stock Identification Methods: Applications in Fishery Science. Amsterdam: Elsevier Academic Press, 719pp.

Childers, J. and Betcher, A. (2010) Summary of the 2008 U.S. North and South Pacific albacore troll fisheries. NOAA Admin. Rep. No. LJ-10-01: 20pp.

Clark, N.E., Blasing, T.J. and Fritts, B.C. (1975) Influence of interannual climate fluctuations on biological systems. Nature 256:302-305.

Clemens, H.B. (1961) The migration, age, and growth of Pacific albacore (Thunnus germo), 1951-1958. Fish. Bull. 115:128pp.

Clemens, H.B. and Craig, W.L. (1965) An analysis of California's albacore fishery. Fish. Bull. 128:301 pp.

Collette, B.B. and Nauen, C.E. (1983) FAO Species Catalogue Vol. 2: Scombrids of the World. An annotated and illustrated catalogue of tunas, mackerels, bonitos, and related species known to date. In: FAO Fisheries Synopsis (FAO) 125:137pp.

Domeier, M.L., Kiefer, D., Nasby-Lucas, N., Wagschal, A. and O'Brien, F. (2005) Tracking Pacific bluefin tuna (Thunnus thynnus orientalis) in the northeastern Pacific with an automated algorithm that estimates latitude by matching seasurface temperature data from satellites with temperature data from tags on fish. Fish. Bull. 103:292-306.

Domokos, R., Seki, M.P., Polovina, J.J. and Hawn, D.R. (2007) Oceanographic investigation of the American Samoa albacore (Thunnus alalunga) habitat and longline fishing grounds. Fish. Oceanogr. 16:555-572.

Fergusson, I.K., Compagno, L.J.V. and Marks, M.A. (2000) Predation by white sharks Carcharodon carcharias (Chondrichthyes: Lamnidae) upon chelonians, with new records from the Mediterranean Sea and a first record of the ocean sunfish Mola mola (Osteichthyes: Molidae) as stomach contents. Environ. Biol. Fish 58:447-453.

Glaser, S. (2010) Interdecadal variability in predator-prey interactions of juvenile North Pacific albacore in the California Current System. Mar. Ecol. Progr. Ser. 414:209-221.

Gunn, J.S., Polacheck, T., Davis, T., Sherlock, M. and Betlehem, A. (1994) The development and use of archival tags for studying the migration, behaviour and physiology of southern bluefin tuna, with an assessment of the potential for transfer of the technology to groundfish research. Proc. I.C.E.S. Mini-Symposium on Fish Migration 21:1-23.

Hill, R.D. and Braun, M.J. (2001) Geolocation by light-level, the next step: latitude. In: Electronic Tagging and Tracking in Marine Fisheries. J.R. Sibert \& J.L. Nielsen (eds) Dordrecht, The Netherlands: Kluwer Academic Publishers, pp. 315330.

Holts, D.B. (1985) Recreational albacore, Thunnus alalunga, fishery by west coast commercial passenger fishery vessels. Mar. Fish. Rev. 47(3):48-53.

Ichinokawa, M., Coan, A.L. and Takeuchi, Y. (2008) Transoceanic migration rates of young North Pacific albacore, Thunnus alalunga, from conventional tagging data. Can. J. Fish. Aquat. Sci. 65:1681-1691.

Jorgensen, S.J., Reeb, C.A., Chapple, T.K. et al. (2010) Philopatry and migration of Pacific white sharks. Proc. R. Soc. B 277:679-688.

Kimura, S., Munenori, N. and Sugimoto, T. (1997) Migrations of albacore, Thunnus alalunga, in the North Pacific Ocean in relation to large oceanic phenomena. Fish. Oceanogr. 6:5157.

Kitagawa, T., Boustany, A.M., Farwell, C., Williams, T.D., Castleton, M. and Block, B.A. (2007) Horizontal and vertical movements of juvenile Pacific bluefin tuna (Thunnus orientalis) in relation to seasons and oceanographic conditions. Fish. Oceanogr. 16:409-421.

Lam, C.H., Nielsen, A. and Sibert, J. (2008) Improving light and temperature based geolocation by unscented Kalman filtering. Fish. Res. 91:15-25.

Laurs, R.M. (1983) The North Pacific albacore - an important visitor to California Current waters. CalCOFI Rep. 24:99106.

Laurs, R.M. and Lynn, R.J. (1977) Seasonal migration of North Pacific albacore, Thunnus alalunga, into North American coastal waters: distribution, relative abundance, and association with Transition Zone waters. Fish. Bull. 75:795822.

Laurs, R.M. and Nishimoto, R. (1979) Summary of findings made by vessels on charter to the Pacific Tuna Development Foundation. NMFS Southwest Fish. Sci. Center Admin. Rep. 111-79-5:38pp.

Laurs, R.M. and Wetherall, J.A. (1981) Growth rates of North Pacific albacore, Thunnus alalunga, based on tag returns. Fish. Bull. 79:293-302.

Laurs, R.M., Yuen, H. and Johnson, J.H. (1977) Small-scale movements of albacore, Thunnus alalunga, in relation to ocean features as indicated by ultrasonic tracking and oceanographic sampling. Fish. Bull. 75:347-355.

Laurs, R.M., Fiedler, P.C. and Montgomery, D.R. (1984) Albacore tuna catch distributions relative to environmental features observed from satellites. Deep-Sea Res. 31:1085-1099.

Lotek Wireless Inc. (2010) Locating Tuna in the Open Ocean. http://www.lotek.com/locatingtuna.pdf. 
Marcinek, D.J., Blackwell, S.B., Dewar, H. et al. (2001) Depth and muscle temperature of Pacific bluefin tuna examined with acoustic and pop-up satellite tags. Mar. Biol. 138:869885.

Murphy, G. (1959) Effect of water clarity on albacore catches. Limnol. Oceanogr. 4:86-93.

Nakamura, H. (1969) Tuna Distribution and Migration. London: Fishing News (Books) Ltd., 76pp.

Nasby-Lucas, N., Dewar, H., Lam, C.H., Goldman, K.J. and Domeier, M.L. (2009) White shark offshore habitat: a behavioral and environmental characterization of the eastern Pacific shared offshore foraging area. PLoS ONE 4: e8163. doi:10.1371/journal.pone.0008163.

Okamoto, H. and Bayliff, W.H. (1999) A review of the Japanese longline fishery for tunas and billfishes in the Eastern Pacific Ocean, 1993-1997. Inter-Am. Trop. Tuna Comm. Bull. $22: 221-375$.

Otsu, T. (1960) Albacore migration and growth in the North Pacific Ocean as estimated from tag recoveries. Pacif. Sci. $14: 257-266$.

Otsu, T. and Uchida, R.N. (1963) Model of the migration of albacore in the North Pacific Ocean. Fish. Bull. 63:33-44.

Pearcy, W.G. (1973) Albacore oceanography off Oregon - 1970. Fish. Bull. 71:489-504.

Pinkas, L., Oliphant, M.S. and Iverson, I.L.K. (1971) Food habits of albacore, bluefin tuna, and bonito in California waters. Fish. Bull. 152:83pp.

Polovina, J.J., Howell, E., Kobayashi, D.R. and Seki, M.P. (2001) The transition zone chlorophyll front, a dynamic global feature defining migration and forage habitat for marine resources. Prog. Oceanogr. 49:469-483.

Powell, B.S., Arango, H.G., Moore, A.M., Di Lorenzo, E., Milliff, R.F. and Foley, D. (2008) 4DVAR data assimilation in the Intra-Americas Sea with the Regional Ocean Modeling System (ROMS). Ocean Model. 25:173188.

Rothschild, B.J. and Yong, M. (1970) Apparent abundance, distribution, and migrations of albacore, Thunnus alalunga, on the North Pacific longline grounds. U.S. Fish Wild. Serv.,
Spec. Sci. Rep. Fish. 623:1-37.

Schaefer, K.M. and Fuller, D.W. (2002) Movements, behavior, and habitat selection of bigeye tuna (Thunnus obesus) in the eastern equatorial Pacific, ascertained through archival tags. Fish. Bull. 100:765-788.

Sibert, J., Musyl, M.K. and Brill, R.W. (2003) Horizontal movements of bigeye tuna (Thunnus obesus) near Hawaii determined by Kalman filter analysis of archival tagging data. Fish. Oceanogr. 12:141-151.

Silverman, B.W. (1986) Density estimation for statistics and data analysis. Monographs on Statistics and Applied Probability 26: London: Chapman and Hall; 176pp.

Stocker, M. (ed.) (2005) Report of the Nineteenth North Pacific Albacore Workshop. Nanaimo, B.C., Canada, 25 November-2 December 2004. Fisheries and Oceans Canada, Pacific Biological Station, Nanaimo, B.C. 127pp.

Sund, P.N., Blackburn, M. and Williams, F. (1981) Tunas and their environment in the Pacific Ocean: a review. Oceanogr. Mar. Biol. Ann. Rev. 19:443-512.

Teo, S.L.H., Boustany, A.M. and Block, B.A. (2007) Oceanographic preferences of Atlantic bluefin tuna, Thunnus thynnus, on their Gulf of Mexico breeding grounds. Mar. Biol. 152:1105-1119.

Ueyanagi, S. (1969) Observations on the distribution of tuna larvae in the Indo-Pacific Ocean with emphasis on the delineation of the spawning areas of albacore, Thunnus alalunga. Bull. Far Seas Fish. Res. Lab. 2:177-256.

Uosaki, K. (2006) Preliminary results obtained from tagging of North Pacific albacore with archival tag. Col. Vol. Sci. Pap. ICCAT 56:1496-1503.

Wilson, S.G., Stewart, B.S., Polovina, J.J., Meekan, M.G., Stevens, J.D. and Galuardi, B. (2007) Accuracy and precision of archival tag data: a multiple-tagging study conducted on a whale shark (Rhincodon typus) in the Indian Ocean. Fish. Oceanogr. 16:547-554.

Zainuddin, M., Kiyofuji, H., Saitoh, K. and Saitoh, S.I. (2006) Using multi-sensor satellite remote sensing and catch data to detect ocean hot spots for albacore (Thunnus alalunga) in the northwestern North Pacific. Deep-Sea Res. II 53:419-431. 